\title{
Engineering geological characterisation of rock masses for design of excavation method and support system of Tanju Tunnel, West Nusa Tenggara, Indonesia
}

\author{
Edden Umaga Dinata ${ }^{1}$, I Gde Budi Indrawan $^{1 *}$, and Arifudin Idrus ${ }^{1}$ \\ ${ }^{1}$ Department of Geological Engineering, Faculty of Engineering, Universitas Gadjah Mada
}

\begin{abstract}
This paper presents experiences with design and construction process of the Tanju Tunnel, West Nusa Tenggara. The objective of this research was to characterize the volcanic and intrusive rock masses for designs of the tunnel excavation method and support system. Engineering geological investigations were carried out, upon which the tunnel stand-up time was estimated and the tunnel excavation method and support system were determined based on the rock mass classifications of RMR (Bieniawski, 1989). The investigation results showed that the tunnel construction area consisted of colluvium, andesite, and tuff breccia. The rock masses were dominated by the andesite, which had UCS of intact rock ranging from 200 to $300 \mathrm{MPa}$ classified as strong intact rock. Based on the RMR value, the andesite was classified as a good quality rock mass. The tunnel had unsupported roof stand-up time approximately 20.000 hours for a $3 \mathrm{~m}$ tunnel span. The recommended tunnel excavation method was full face, $1.0-1.5 \mathrm{~m}$ advance, and complete support $20 \mathrm{~m}$ from face, while the support systems were locally bolt in crown $3 \mathrm{~m}$ long and $2.5 \mathrm{~m}$ spacing, with occasional wire mesh, $50 \mathrm{~mm}$ thick shotcrete in crown where required.
\end{abstract}

\section{Introduction}

This research is carried out at the construction site of Tanju Tunnel, which is administratively, located in the village of Bara, Woja, Dompu District, West Nusa Tenggara (Fig. 1). The drainage tunnel is built to drain a $1.9 \mathrm{~m}^{3} / \mathrm{s}$ water to fill Tanju Dam. The Tanju Dam has a very large reservoir, but its inflow potential is limited. In order to cover the lack of inflow into the reservoir, a $3 \mathrm{~m}$ diameter and $1.6 \mathrm{~km}$ long drainage tunnel is needed to convey water from the Rababaka River to Tanju Dam. The most effective and safe excavation method needs to be determined.

Several investigations were carried out in the tunnel construction design stage, including the rock mass characterizations for designs of the tunnel excavation method and support system. This paper presents results of engineering geological investigations to characterize the rock masses at the Tanju Tunnel construction site. Results of the rock mass characterization for designs of the tunnel excavation method and support system are described. The adopted excavation method and support system during the tunnel construction are presented. It is expected that this paper provides a better understanding of drainage tunnel design and construction in tropical regions, particularly in Indonesia.

\section{Literature review}

Based on the Regional Geological Map, the island of Sumbawa is composed of pyroclastic rocks and sedimentary rocks formed in the Miocene to Quaternary age [1].

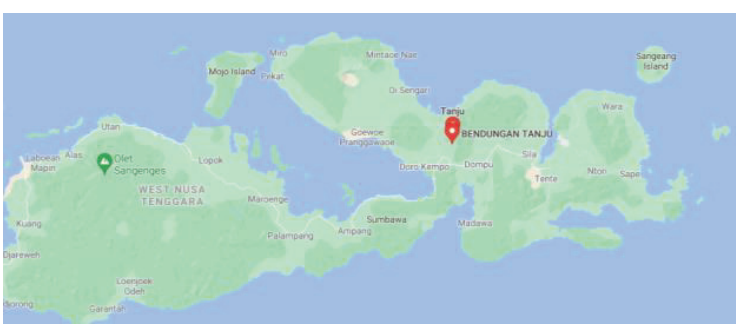

Fig. 1. Research location.

Part of the regional geological map of Sumbawa Island around the Tanju Tunnel construction site is shown in Fig. 2. Based on the regional geological map, the research location is composed of old volcanic rock products (Qvl) of Quaternary age and tuff breccia unit (Tmv) of Tertiary age. The Quaternary rock unit consists of volcanic sedimentary rocks, alluvial deposits and river sediments of the Recent age, while the Tertiary rock unit consists of alternating between breccias, lava and tuffs with a composition of andesite and basalt.

\footnotetext{
*Corresponding author: igbindrawan@ugm.ac.id.
} 


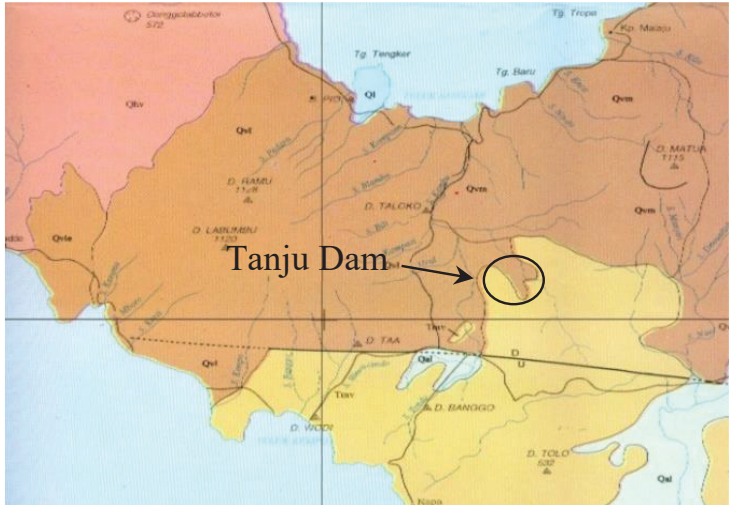

Fig. 2. Regional Geology Map of Sumbawa [1].

Rock masses are generally inhomogeneous, inelastic, discontinuous and anisotropic media [2]. Such properties make their characterization more complex and difficult [2]. Methods commonly used for rock mass classification include the Q index [3], Rock Mass Rating [4], and the Geological Strength Index [4]. These methods are very commonly used in projects, especially tunnels.

Table ). This guideline can be applied with both conventional digging and blasting. A number of previous studies $[6,7,8,9,10]$ used the RMR for designs of tunnel excavation method and support system.

\section{Research methodology}

The research was conducted through surface and subsurface geological mapping and rock mass classification mapping. The naming of volcanic rocks in the study area was carried out based on the classification of Fischer and Table .

Table 1. Rock Mass Quality Class based on RMR [4].

\begin{tabular}{|l|l|l|l|l|l|}
\hline $\begin{array}{l}\text { Rock } \\
\text { Class }\end{array}$ & $\begin{array}{l}\text { Very } \\
\text { Poor }\end{array}$ & Poor & Fair & Good & $\begin{array}{c}\text { Very } \\
\text { Good }\end{array}$ \\
\hline
\end{tabular}

The RMR [4] rock mass classification consists of 6 (six) parameters. RMR [4] system incorporates six parameters namely: 1) Uniaxial Compressive Strength (UCS) from intact rock ( $\sigma c), 2$ ) Rock Quality Designation (RQD), 3) Spacing of discontinuity, 4) Condition of discontinuity surface, 5) Ground water condition, 6) Orientation of discontinuity relative to structure. Value of those six RMR parameters afterward was determined based on the table by Bieniawski [4]. These parameters can be obtained by doing measurements of outcrops in the field or drilling cores. The assessment area must be divided into regions that have the same character, especially seen from the structural characteristics both quality and quantity. Based on the total RMR [4] value obtained from the calculation of the parameters, the rock masses are classified into 5 (five) classes of quality, as shown in Table . Bieniawski (1989) provides a recommendation for tunnel excavation methods and support systems based on the RMR value [4] (

Scmidt [11], while the naming of intrusive rocks was carried out based on the rock classification compiled by Travis [12]. Geological structures were analyzed based on analysis of satellite images and field observations. Determination of RMR parameters were carried out by a face mapping during tunnel construction [4]. The tunnel excavation method and support system were determined following recommendation as shown

\begin{tabular}{|c|c|c|c|c|c|}
$\begin{array}{c}\text { RMR } \\
\text { Rating }\end{array}$ & $<20$ & $21-40$ & $41-60$ & $61-80$ & $81-100$ \\
\hline
\end{tabular}

Table 2. Guide for excavation and tunnel support systems of 10 meters span with the RMR system [4].

\begin{tabular}{|c|c|c|c|c|c|}
\hline \multicolumn{2}{|c|}{ Rock Mass Class } & \multirow[b]{2}{*}{ Excavation Method } & \multicolumn{3}{|c|}{ Support System } \\
\hline Class & $\begin{array}{l}\text { RMR } \\
\text { Value }\end{array}$ & & $\begin{array}{l}\text { Rock Bolts } \\
(\mathrm{d}=20 \mathrm{~mm})\end{array}$ & Shotcrete & Steel Sets \\
\hline $\begin{array}{l}\text { Very } \\
\text { Good }\end{array}$ & $81-100$ & $\begin{array}{l}\text { Full face } \\
3 \mathrm{~m} \text { advance }\end{array}$ & \multicolumn{3}{|c|}{$\begin{array}{l}\text { Generally, no support required except for occasional } \\
\text { spot bolting }\end{array}$} \\
\hline Good & $61-80$ & $\begin{array}{l}\text { Full Face } \\
1.0 \text { - } 1.5 \mathrm{~m} \text { advance } \\
\text { Complete support } 20 \mathrm{~m} \\
\text { from face }\end{array}$ & $\begin{array}{l}\text { Locally, bolts in } \\
\text { crown } 3 \mathrm{~m} \text { long, } \\
\text { spaced } 2.5 \mathrm{~m} \text {, with } \\
\text { occasional wire } \\
\text { mesh }\end{array}$ & $\begin{array}{l}50 \mathrm{~mm} \text { in crown } \\
\text { where required }\end{array}$ & None \\
\hline
\end{tabular}




\begin{tabular}{|c|c|c|c|c|c|}
\hline Fair & $41-60$ & $\begin{array}{l}\text { Top Heading and Bench } \\
1.5-3 \mathrm{~m} \text { advance in top } \\
\text { heading } \\
\text { Commence support after } \\
\text { each blast.Complete } \\
\text { support } 10 \mathrm{~m} \text { from face }\end{array}$ & $\begin{array}{l}\text { Systematic bolts } 4 \\
\mathrm{~m} \text { long, } \\
\text { spaced } 1.5-2 \mathrm{~m} \text { in } \\
\text { crown and walls } \\
\text { with wire mesh in } \\
\text { crown }\end{array}$ & $\begin{array}{l}50-100 \mathrm{~mm} \text { in } \\
\text { crown and } 30 \\
\mathrm{~mm} \text { in sides }\end{array}$ & None \\
\hline \multicolumn{2}{|c|}{ Rock Mass Class } & \multirow[b]{2}{*}{ Excavation Method } & \multicolumn{3}{|c|}{ Support System } \\
\hline Class & $\begin{array}{l}\text { RMR } \\
\text { Value }\end{array}$ & & $\begin{array}{l}\text { Rock Bolts } \\
(\mathrm{d}=20 \mathrm{~mm})\end{array}$ & Shotcrete & Steel Sets \\
\hline Poor & $21-40$ & $\begin{array}{l}\text { Top Heading and Bench } \\
1.0-1.5 \mathrm{~m} \text { advance in top } \\
\text { heading } \\
\text { Install support concurrently } \\
\text { with excavation } 10 \mathrm{~m} \text { from } \\
\text { face }\end{array}$ & $\begin{array}{l}\text { Systematic bolts } 4- \\
5 \mathrm{~m} \text { long, spaced } \\
1-1.5 \mathrm{~m} \text { in crown } \\
\text { and wall with wire } \\
\text { mesh }\end{array}$ & $\begin{array}{l}100-150 \mathrm{~mm} \text { in } \\
\text { crown and } 100 \\
\mathrm{~mm} \text { in sides }\end{array}$ & $\begin{array}{l}\text { Light to medium } \\
\text { ribs spaced } 1.5 \mathrm{~m} \\
\text { where required }\end{array}$ \\
\hline $\begin{array}{l}\text { Very } \\
\text { Poor }\end{array}$ & $<20$ & $\begin{array}{l}\text { Multiple drifts } 0.5-1.5 \mathrm{~m} \\
\text { advance in top heading. } \\
\text { Install support concurrently } \\
\text { with excavation. Shotcrete } \\
\text { as soon as possible after } \\
\text { blasting. }\end{array}$ & $\begin{array}{l}\text { Systematic bolts } 5- \\
6 \mathrm{~m} \text { long, spaced } \\
1-1.5 \mathrm{~m} \text { in crown } \\
\text { and wall with wire } \\
\text { mesh. Bolts invert }\end{array}$ & $\begin{array}{l}150-200 \mathrm{~mm} \text { in } \\
\text { crown, } 150 \mathrm{~mm} \\
\text { in sides, and } 50 \\
\mathrm{~mm} \text { on face }\end{array}$ & $\begin{array}{l}\text { Medium to heavy } \\
\text { ribs spaced } 0.75 \mathrm{~m} \\
\text { with steel lagging } \\
\text { and fore polling if } \\
\text { required. Close } \\
\text { invert }\end{array}$ \\
\hline
\end{tabular}

\section{Results and discussion}

The research area has hilly morphological conditions where the Tanju Tunnel cuts a ridge that extends in a relatively northeast-southwest direction. The ridge is about $2.2 \mathrm{~km}$ long and has a $320 \mathrm{~m}$ peak elevation. The slopes around the tunnel construction location are quite steep, ranging from $45^{\circ}$ to $60^{\circ}$. The inlet of Tanju Tunnel is located at $+124.45 \mathrm{~m}$ elevation, while the outlet is located at +124.27 m elevation.

In general, the area of the Tanju Tunnel construction site consists of three rock units, namely colluvium, andesite, and tuff breccia. The andesite and tuff breccia near and at the ground surface are mostly weathered (Fig. 3 to Fig. 6). The colluvium in the form of a mixture of black clay and $2-10 \mathrm{~cm}$ andesite fragments is widely found on the soil surface, especially on the slopes of the hills downstream of the tunnel. The thickness varies from 2 to $6 \mathrm{~m}$ (Fig. 3). Moderately to higly weathered andesite [13] are often converted into soil mixed with $5-50 \mathrm{~cm}$ andesite fragments, which are abundant on the soil surface in the hilly area around the upstream tunnel.

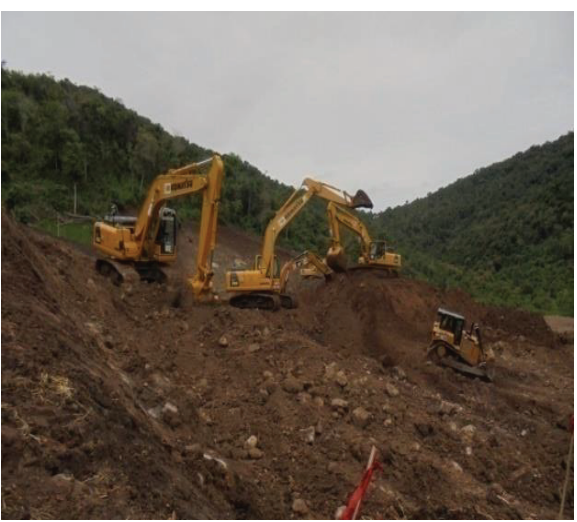

Fig. 3. Colluvium consists of black clay and $2-10 \mathrm{~cm}$ andesite fragments.

The fresh to slightly weathered andesite is gray, hard and compact, which is the bedrock of the upstream tunnel. Most of the tunnels from upstream to middle will pass through this rock mass. Laboratory testing carried out on 2 (two) samples, namely the "drilling core" TR-1 at a depth between $61.65-62.00 \mathrm{~m}$ and $64.5-65.0 \mathrm{~m}$, show that the andesite has $200-300 \mathrm{MPa}$ uniaxial compressive strength (UCS) value and is classified as very strong to extremely strong rock based on the ISRM (1981) classification. 


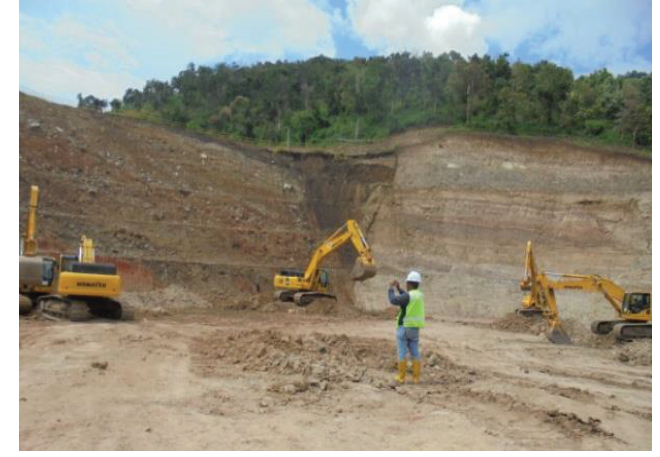

Fig. 4. Moderately to highly weathered andesite.

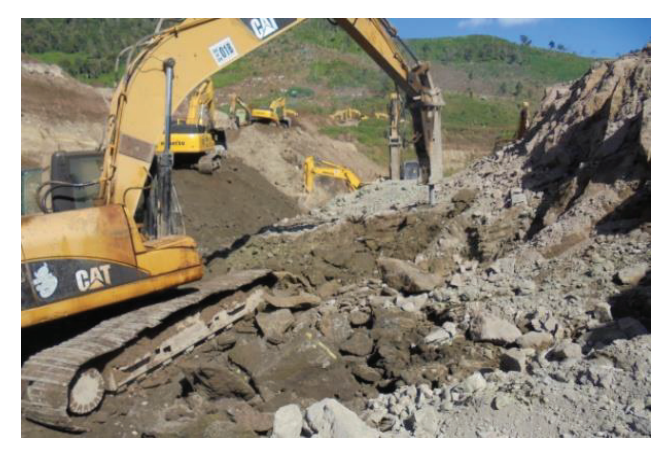

Fig. 5. Tuff breccia. 


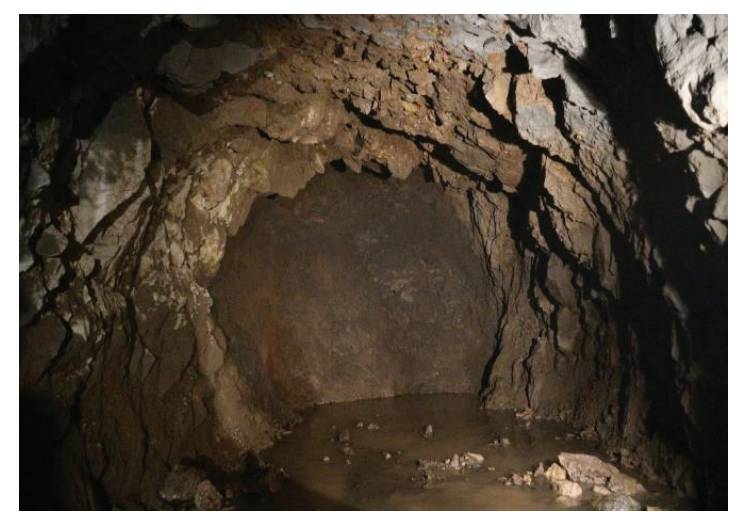

Fig. 6. Fresh to slightly weathered andesite.

Tuff breccia are brownish gray in color and have a relatively abundant of tuff matrix compared to the fragments, which are generally relatively small, about 2 to $5 \mathrm{~cm}$ in size. Tuff matrix is grayish brown to whitish, hard and massive. The fragments generally consist of andesite fragments, hard and relatively tapered. Weathered tuff breccia rocks in the form of a mixture of clay and $2-50 \mathrm{~cm}$ andesite fragments and tuff breccia are abundant in the downstream Tanju Tunnel. It is located below the colluvium to a depth of $21.50 \mathrm{~m}$ to more than $25 \mathrm{~m}$ below ground level. Due to the weak rock engineering properties, drainage section through this rock mass uses conduit, instead of tunnel, and will be backfilled later (Fig. 5). Engineering geological profile of the rock masses along the Tanju Tunnel is shown in Fig. 7.

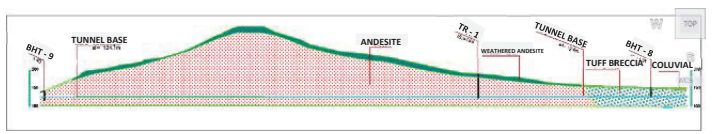

Fig. 7. Engineering geological profile along Tanju Tunnel.

At the tunnel elevation, the fresh to slightly weathered andesite has $90 \% \mathrm{RQD}$, less than $50 \mathrm{~cm}$ joint spacing, and damp groundwater condition. Based on the ratings of each parameter in Table 2, the andesite rock mass at the tunnel elevation has, consequently, a 65 total RMR value and is classified as good quality. Based on Bieniawski [4], the excavation method recommended for the good quality rock mass is full face, $1.0-1.5 \mathrm{~m}$ advance, and complete support 20 meters from face (Table 2).

As the andesite rock masses have 65 RMR value and the tunnel has $3 \mathrm{~m}$ roof span, Fig. 8 shows that the stand-up time for the unsupported tunnel during excavation will be 20.000 hours ( 27 months 13 days). Based on geological observations on the ground surface or through the results of existing drilling, there were no indications of weak zones, such as fracture, along the tunnel route. In addition, the andesite rock masses also have high UCS value of intact rock and good rock mass quality.

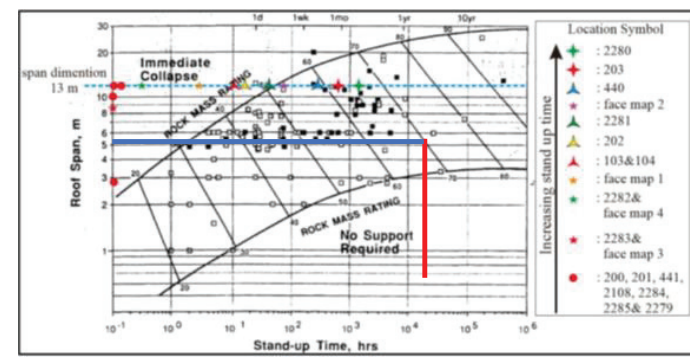

Fig. 8. Stand-up time of the excavated tunnel.

To facilitate a full face excavation method, as recommended by the RMR value, the rock masses were excavated by drilling and blasting method in the construction process (Fig. 9a, 9b, 9c). The typical rock mass condition after blasting is shown in Fig. 10. The long tunnel stand-up time predicted in Fig. 8 was confirmed during relative long drilling and blasting processes of the tunnel construction. As also recommended by the RMR value, the support system selected for the tunnel was wire mesh and shotcrete with locally bolt in crown (Fig. 11).

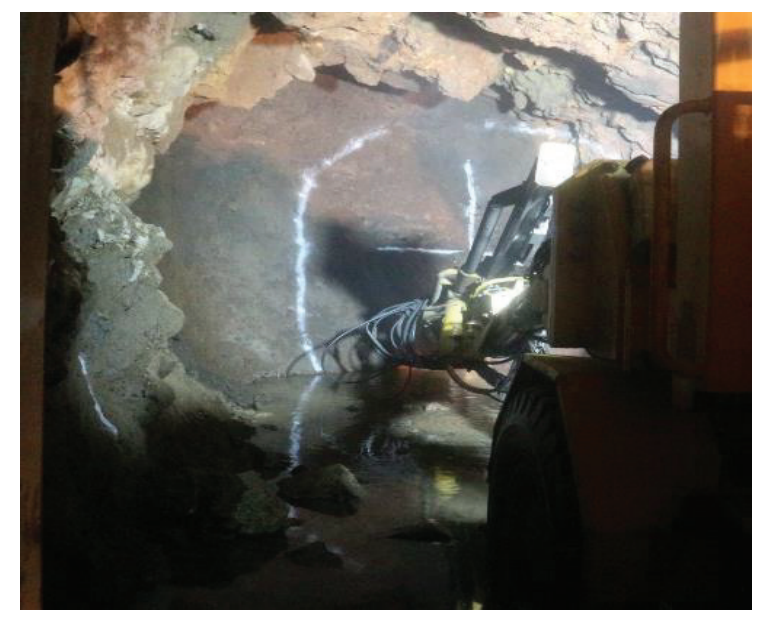

Fig. 9a. Tunnel excavation: Drilling.

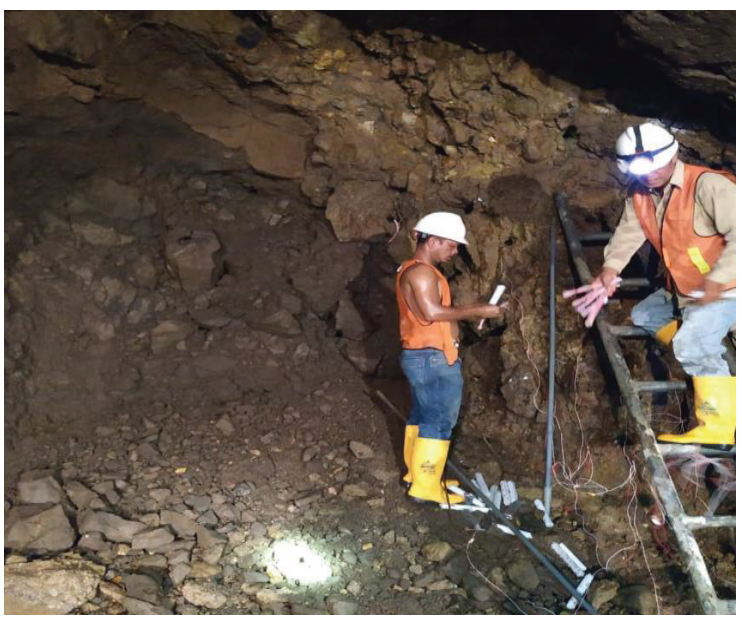

Fig. 9b. Tunnel excavation: Charging. 


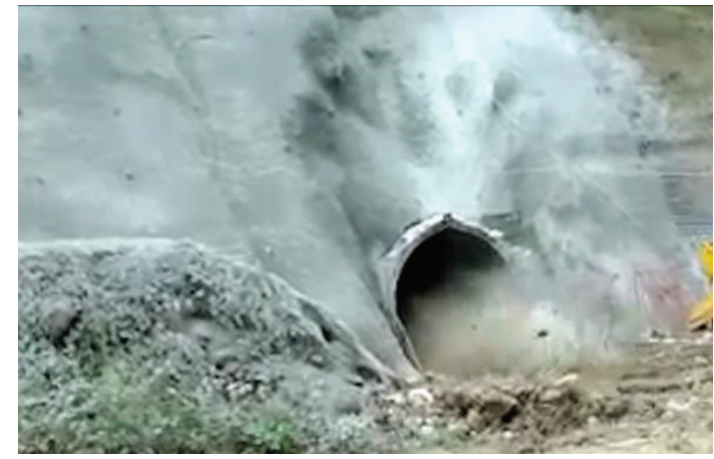

Fig. 9c. Tunnel excavation: Blasting.

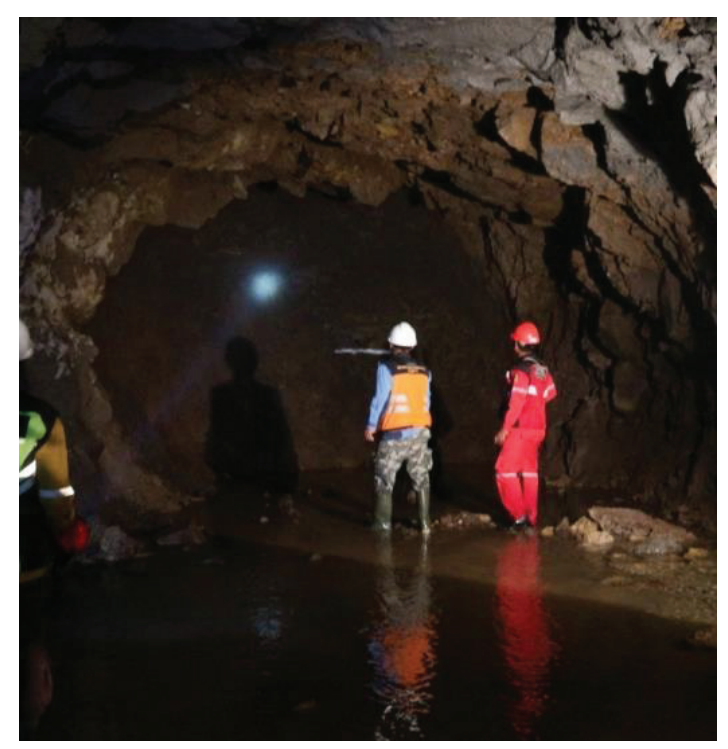

Fig. 10. Typical rock mass condition after blasting.

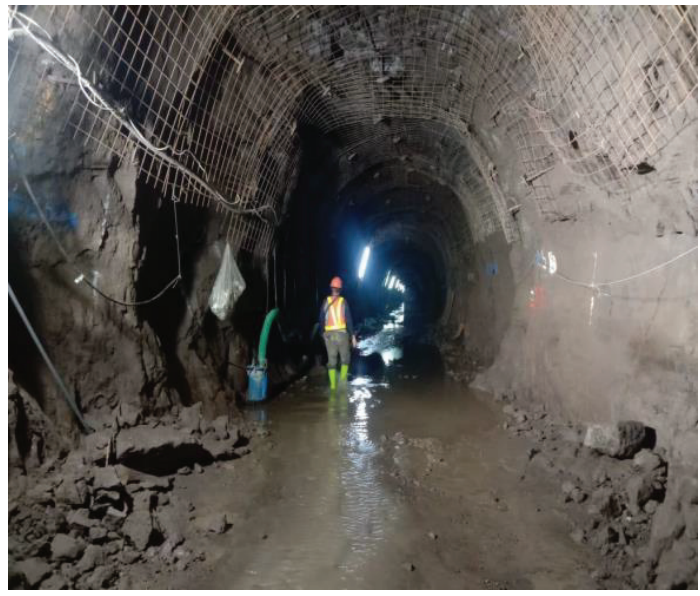

Fig. 11. Rock bolt, wire mesh, and shotcrete installations.

\section{Conclusion and recommendation}

The tunnel construction area consisted of colluvium, andesite, and tuff breccia. The rock masses surrounding the tunnel were dominated by the andesite, which had uniaxial compressive strength (UCS) of intact rock ranging from 200 to $300 \mathrm{MPa}$ and, therefore, classified as strong to extremely strong intact rock. Based on the RMR value, the andesite was classified as good quality rock mass. Drilling and blasting is the most effective method to do the excavation based on the rock mass quality. The recommended tunnel excavation method based on the RMR value was full face, $1.0-1.5 \mathrm{~m}$ advance, and complete support $20 \mathrm{~m}$ from face, while the recommended tunnel support systems were locally bolt in crown $3 \mathrm{~m}$ long and $2.5 \mathrm{~m}$ spacing, with occasional wire mesh, $50 \mathrm{~mm}$ thick shotcrete in crown where required [4]. The tunnel had unsupported roof stand-up time approximately 20.000 hours for a $3 \mathrm{~m}$ tunnel span.

Further research is necessary to analyse stability of the Tanju Tunnel, such as by numerical method, to obtain better understanding the rock mass and support system interaction.

The authors would like to thank BWS Nusa Tenggara 1, Supervision Consultant, and PT. Nindya Karya for the permission to this study and to publish the results.

\section{References}

1. A. Sudrajat, S. Andi Mangga, N. Suwarna, Peta Geologi Lembar Sumbawa, Nusatenggara (1998)

2. F. Ceballos, C. Olalla, R. Jimenez, Relationship between RMRb and GSI based on in situ data (Eurock, Spain, 2014)

3. N. Barton, R. Lien, J. Lunde, Rock Mech. 6, 4, 189236 (1974)

4. Z. T. Bieniawski, Engineering rock mass classifications: a complete manual for engineers and geologists in mining, civil, and petroleum engineering (John Wiley \& Sons, New York 1989)

5. E. Hoek, ISRM News Journal 2, 4-16 (1994)

6 . J. Ranasooriya, The reliability of rock mass classification systems as underground excavation support design tools (Doctoral dissertation, Curtin University, 2009)

7. A.R. Lowson and Z.T. Bieniawski, Critical Assessment of RMR based tunnel design practices: a practical engineer's approach, in Rapid Excavation \& Tunneling Conference, Washington, DC, 23-26 (2013)

8. A. Rahmati, L.Faramarzi, M. Sanei, Frontiers of Structural and Civil Engineering, 8, 4, 448-455 (2014).

9. V. Santos, P. F. Da Silva, M.G. Brito, Minerals 8, 3, 78 (2018)

10. M.S. Akram, M. Zeeshan, M. Haroon, K. Mirza, Open Journal of Geology 9, 11, 809-828 (2019)

11. J. McPhie, M. Doyle, R. Allen, Volcanic textures: a guide to the interpretation of textures in volcanic rocks (Tasmanian Government Printing Office, Tasmania, 1993)

12. R.B. Travis, Classification of Rocks. Colorado School of Mines, $\mathbf{5 0}$ (1955) 
13. ISRM, The complete ISRM suggested methods for rock characterization, Testing and Monitoring, Ankara. ISRM Turkish National Group (1981) 